\title{
Multiple Minor Histocompatibility Antigen Disparities Between a Recipient and Four HLA-Identical Potential Sibling Donors for Bone Marrow Transplantation
}

\author{
Erik A. F. Marijt, Willy F. J. Veenhof, Els Goulmy, \\ Petra M. C. Kluck, Anneke Brand, Roel Willemze, \\ Jon J. van Rood, and J. H. Fred Falkenburg
}

\begin{abstract}
A patient with acute leukemia and her family including four HLA-identical siblings were analyzed to select a donor who was not only HLA- but also minor histocompatibility $(\mathrm{mH})$ antigen compatible for allogeneic bone marrow transplantation (BMT) The HLAA2 restricted $\mathrm{mH}$ antigen-specific $\mathrm{HA}-1,-2,-4$, and -5 cytotoxic T-lymphocyte (CTL) clones were used to type the family members for expression of these $\mathrm{mH}$ antigens The patient and one HLA-identical sibling were compatible for these $\mathrm{mH}$ antigens This sibling was selected as the bone marrow donor The patient engrafted promptly but developed acute and chronic graft-versus-host disease To study the presence of other $\mathrm{mH}$ antigen dispar1ties between recipient and donor, host-versus-graft CTL lines and clones were generated by stimulation of recipient peripheral blood lymphocytes (PBLs) with donor bone marrow cells, and graft-versus-host CTL lines were generated after BMT by stimulation of PBLs of donor origin with recipient bone marrow cells These CTL lines were cytotoxic to cells from the bone marrow donor and
\end{abstract}

$\begin{array}{ll}\text { ABBREVIATIONS } \\ \text { aGvHD } & \text { acute graft-versus-host disease } \\ \text { BMMNC } & \text { bone marrow mononuclear cell } \\ \text { BMT } & \text { bonf marrow transplantation } \\ \text { CTL } & \text { cytotoxic T lymphocyte } \\ \text { EBV } & \text { Epstein-Barr virus } \\ \text { GvH } & \text { graft versus host } \\ \text { HvG } & \text { host versus graft } \\ \text { IL-2 } & \text { interleukin } 2 \\ \text { LCL } & \text { lymphoblastord cell line }\end{array}$

From the Laboratory of Experimental Hematology (W AFM W FJV,P M $C K, R W, J H F F$ ) and the Department of Immunobematology and Bloodbank (WAFM EG AB IJiR), Leiden The Netherlands

Address reprint requests to $\mathrm{Dr}$ W A F Marzt Department of Hematology, Bulding 1, C2-R, Unvversity Medical Center Rumsburgerweg 10 2333 AA Leiden, The Netberlands

Received (U) February 13 1993, accepted July I 1993 from the recipient, respectively, and to cells from several other family members $T$-cell lines, generated from the patient after BMT by stimulation of recipient-derived PBLs with donor bone marrow cells, exhibited no specific cytotoxicity to donor or recipient cells Chimerism studles after BMT revealed that the PBLs and T-cell lines generated after BMT were of donor origin CTL lines that were generated from PBLs from the three other HLA-identical siblings in this family by stimulation with HLA-identical donor bone marrow cells also exhibited cytotoxicity to cells from several family members Our results show that in addition to compatibility for HA-1, $-2,-4$, and -5 between the recipient and the donor, other $\mathrm{mH}$ antigen disparities existed between all HLA-identical siblings, illustrating the high degree of polymorphism of $\mathrm{mH}$ antigens and therefore the difficulty of finding $\mathrm{mH}$ antigen-compatible donor-recipient pairs even when more than one HLA-identical sibling is present within a family Human Immunology 37, 221-228 (1993) 
TABLE 2 Reactivity of recipient derived $\alpha$ donor bone marrow CTL linc, and clones

\begin{tabular}{|c|c|c|c|c|c|c|c|c|c|}
\hline \multirow[b]{2}{*}{$\begin{array}{c}\text { Effector } \\
\text { cells }\end{array}$} & \multicolumn{9}{|c|}{ Specific lysis in "I $\mathrm{r}$ releasc assay of IL 2 blasts from } \\
\hline & $\begin{array}{c}\text { Donor } \\
\mathrm{at}^{b}\end{array}$ & $\begin{array}{c}\text { Rec } \\
\text { ac }\end{array}$ & $\begin{array}{c}\text { Stb } 3 \\
a c\end{array}$ & $\begin{array}{c}\text { Stb } 4 \\
d c\end{array}$ & $\begin{array}{c}\text { Stb } 5 \\
\text { ac }\end{array}$ & $\begin{array}{c}\text { Sib } 6 \\
\text { ad }\end{array}$ & $\begin{array}{c}\text { Sib } 7 \\
\text { ad }\end{array}$ & $\begin{array}{c}\text { Sibs } 8 \\
\text { bl }\end{array}$ & $\begin{array}{c}\text { M ther } \\
<1\end{array}$ \\
\hline CrL line $\mathrm{I}^{a}$ & +++ & - & & +++ & - & & $+t+$ & & \\
\hline CTL line I A & +++ & - & $++t$ & ++ & +++ & & $t+t$ & & $t+t$ \\
\hline CTL lane I B & $+t$ & & $+t$ & ++ & ++ & - & & & \\
\hline Clone $10 \Gamma 8^{d}$ & $++t$ & - & - & +++ & - & & $t+t$ & & \\
\hline
\end{tabular}

- Effectot-target ratio $20 \quad 1$

'See Table 1 noter

See Table 1 notcs

\&Effecer r target zatios $\$ 1$

clones with the same specificity CTL clone $10 \mathrm{E} 8$ is a representatuve examplc of these clones that recognized cells from the bone marrow donor and from siblings 4 and 7 Phenotypic analysis of the clones by FACS scan ning, using anti-CD3, -CD4, and CD8 monoclonal an tibodies (Becton-Dickınson, Mountan View CA USA) showed that they were $\mathrm{CD} 3^{+} \mathrm{CD} 8{ }^{+}$These results show that CTL lines can be generated with vars ous $\mathrm{mH}$ antigen specificities from pre BMT recipient PBLs by stimulation with donor BMMNCs

Recogntion of cell from family members by GvH CTL lines Table 3 shows that the CTL lines generated from PBLs collected at several intervals after BMT and stımu lated with irradiated recipient pretransplant BMMNCs differentually recognized celis from other family mem bers, which suggested the presence of different $\mathrm{mH}$ antigen specificities in the GvH CTL lines

Recognition of cells from famtly members by the stbling 34 and 5-antidonor CTL lines CTL lines were generated from PBLs from three other HLA identical siblings by stimulation with irradiated donor BMMNCs Table 4 shows that these CTL lincs differenerally recognized cells from other family mombers CTL linc 4-antydonor only lysed to a limited cxtcnd EBV LCLs from the do nor but not IL 2 blasts

Lack of donor spectic recogntion by port BMI antidonon bone marrow $\Gamma$ cell lina $\Gamma 0$ investigatc the presence of residual potcntial donor directed CTLs in the periph eral blood of the recipient after BMT PBLs collected on days $+14+19+27+40+60$ and +180 werc stimulated with irradiatcd donor BMMNCs I cell hincs gencrated from PBLs collected on days $+14+19+27$ and +40 were nether cytotoxic for cells from the recip ient nor for cclls from the bone marrow donor Cyto toxicity aga!nst EBV LCLs but not IL 2 bl tsts from re copient and bone marrow donor werc detceted in the T cell lincs generated from PBLs collectcd on days +60 and +180 and that had been strmulated with donor BMMNCs only The obscrved cytotoxicity was not do nor specific however since autologous cclls ilso were recognized (data not shown) Dctermunation of the ors gin of the $\Gamma$ cell lines generated after BMT sboucd that they all were donor derived (l $\lg 1)$

TABLE 3 Reactivity of GvH CTL lines



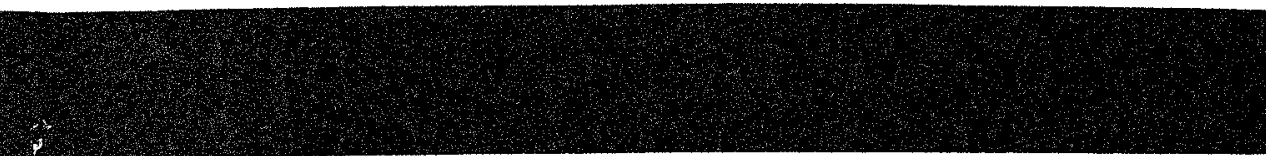


I ABLI 4 Reactrvity of siblong 3, 1, and 5-ancidonor ( TL incs

\begin{tabular}{|c|c|c|c|c|c|c|c|c|c|c|c|}
\hline \multirow[b]{2}{*}{ Iffectses ass } & \multicolumn{11}{|c|}{ 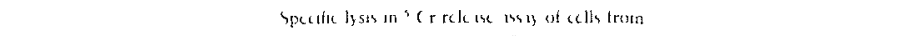 } \\
\hline & $\begin{array}{c}\text { Domor } \\
\text { II } 2 \\
\text { blats } \\
x^{\prime}\end{array}$ & $\begin{array}{c}1 B V \\
1 C_{13} \\
{ }_{x}\end{array}$ & $\begin{array}{l}\text { Rea } \\
\text { IL } \\
\text { blist } \\
\text { at }\end{array}$ & $\begin{array}{c}\text { I BV } \\
\text { LC } 14 \\
\text { in }\end{array}$ & $\begin{array}{l}\operatorname{sib} 3 \\
\text { II } 2 \\
b \mid \begin{array}{l}\text { ists } \\
\text { de }\end{array}\end{array}$ & $\begin{array}{c}\text { Sib t } \\
\text { II ? } \\
\text { bists } \\
\text { in }\end{array}$ & $\begin{array}{l}\text { sal } 5 \\
\text { if } 2 \\
\text { blasts } \\
\text { ac }\end{array}$ & $\begin{array}{c}\text { Sube } \\
\text { II ? } \\
\text { biasty } \\
\text { ud }\end{array}$ & $\begin{array}{c}\text { Sib } 7 \\
\text { II } 2 \\
\text { blasis } \\
\text { dit }\end{array}$ & $\begin{array}{c}\text { yh } 8 \\
\text { II } 2 \\
\text { blasts } \\
\text { but }\end{array}$ & $\begin{array}{c}\text { Mother } \\
112 \\
\text { Dasts } \\
\text { cd }\end{array}$ \\
\hline $\begin{array}{l}\text { (I) line } 3 \text { ax denor } \\
\text { (T) line } 4 x \text { denor }\end{array}$ & 11 & $i+i$ & & +++ & & - & & +++ & $\begin{array}{l}\mathrm{ND}^{\prime} \\
\mathrm{ND}\end{array}$ & +++ & ++1 \\
\hline (II) han 5 ax donor & $i t$ & +1 & & $t+t$ & - & & & + & ND & $+t$ & \\
\hline
\end{tabular}

iffectsi lirket ratt) 201

* See l hible I neses

hec I the I wistes

'Nor I ne

\section{DISC USSION}

HLA identical BMT mily be complicated by severe aGvHD or gratt rejecreon despete optumal matching for HLA class 1 and II antigens $\{1-7\}$ Both complications are thought to be the result of the recognateon of $\mathrm{mH}$ antigens by ammunocompcent $T$ lymphocytes from donor or recipic or orighn, respectuvely [2 13] Minos hiscocompatibility antigens are thoughe to be peptedes de rived from cellutar protems $\{26\}$ that are bound in the groove of major histocompatibility complex ( $\mathrm{MHC}$ ) molecules This MHC nolcule-puptuk complex can be recognazed by alloreative $[$ ty mphocytes [27] Consequently, matching for $\mathrm{mH}$ andue as berween donor

rigLeR 1 RILP andis sis vaped for Pe R amplificateon, of PBLs from the bone matros donor and the recupsent, and of the poster unsplatat ustulonor bone marow $T$ celt lanes the bandís lepresent PC R amplificd DNA liak marked + are

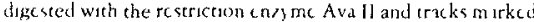

ure undigested 1 rarke $I$ and 2 are donor cell derived and produce only one band, whereas liak ecll derived and producc two bands when digisted with Ava ll (track 4) Recipient ind donor celis were collected beforc BMI Traks 5-16 are derived from recipunt post BMT ant donor BMMNC T ecll lines, gencruted from recuplent PBLs sollected $14-180$ days after BMT and recipient may decrease the incidence and severity of aGvHD and graft rejecton

In mice, more than $50 \mathrm{mH}$ genes have been describal [28] In humans, several durhors have described $\mathrm{mH}$ antigen specific CTLs in patients after muituple blood transfusions and bone marrow and kidney transplanttion [2, 29-32] Mapping of the gene loc has been successful only for the male $\mathrm{mH}$ antigen $\mathrm{H} \mathrm{Y}$, both in humans and mice $[33,34]$, and for MTF, a mouse $\mathrm{mH}$ antigen encoded by mitochondrial DNA [35] lf the polymorphism of immunogenuc human $\mathrm{mH}$ antigens is as extended as tn mice, the chances of finding donorrecipient pars adentical for both major and minor histocompatibility antigens may be limited

Previously, we have shown that, prior to BMT, rceipsent-antidonor cytotoxicity was demonstrated in seven of ten HLA-ritentical donor-recipient pars [2!] In the prescnt study, we show that although donor and recipr ent were matched for the $\mathrm{mH}$ antgens $\mathrm{HA}-1,-2,-4$, and -5 , additional cy totoxic reactivity aganst other, as yet undefined, $\mathrm{mH}$ antigens was present berween these two siblings, both in the GvH and the HvG directions The duferences in rccognition patterns between the HvG warent line and tis sublines and beiwcen the GvH lines generated at different time intervals after BM $\Gamma$

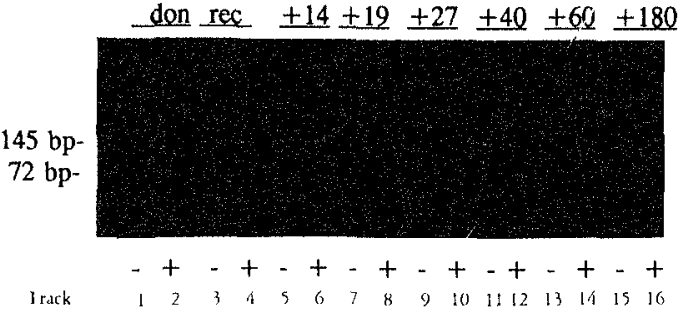


may reflect differences in the frequencies of the various $\mathrm{mH}$ antigen-specific CTL clones present in the CTL lines The differential reacuvity of the post-BMT GvH CTL lines may reflect in wivo sensitizarion of donor $T$ cells aganst $\mathrm{mH}$ anugens These $\mathrm{mH}$ antigens may be sequentially expressed on recipient stimulator cells, e $g$, due to sequentual infections by pathogens that upregulate expression of various self-mH antigens In addition, when PBLs from the three other HLA-identical siblings were stimulated with irradiated donor BMMNCs, CTL lines were generated that also recognized $\mathrm{mH}$ antugens expressed on cells from family members These results illustrate multuple $\mathrm{mH}$ antigen disparitues between the HLA-1dentical family members

Despite the presence of host-antidonor cytotoxic reactivity prior to BMT, no graft rejection occurred No residual recipient cells were demonstrated in peripheral blood and bone marrow collected from the recipient by chimerism studies after BMT These findings were in accordance with the inability to generate recipient-antidonor CTL lines from posttransplant PBLs, suggesting that no functional alloredctive recıpient $T$ lymphocytes were present after BMT These findings can be explained by the eradication of recipient-immunocompetent $T$ cells by the conditioning regimen $[36,37]$, by their suppression by $T$ cells from the graft $[3]$, or by the posttransplant immunosuppressive therapy [38] Uncomplicated engraftment despite in vitro $\mathrm{HvG}$ reactivsty prior to BMT agrees with a previous report [21] in which we describe that, in seven of ten HLA-identical donor-recipient paurs, reciplent-antidonor CTL lines were generated before BMT None of these patients showed signs of graft fallure or graft rejection

GvHD was not prevented by matching for expression of the mH antigens $\mathrm{HA}-1,-2,-4$, and -5 , suggestung that also in the $\mathrm{GvH}$ direction additional $\mathrm{mH}$ antigen disparities were present between donor and recipient Our in vitro results with $\mathbf{T}$-cell lines, generated by stimulation of PBLs collected at several intervals after BMT with recipient pre-BMT BMMNCs, paralleled the in vivo observed GVH teactivity Van Els et al [39] could not demonstrate a clear correlation between the incldence of GvHD and the ability, or inability, to generate anthost CTL lines after BMT Together the results reported here and those by Van Els et al indicate that most donor-recipient pairs are $\mathrm{mH}$ antigen disparate, but that there is not necessarlly a relation between the ability, or inability, to generate CTL lines that lyse reciptent or donor cells and the occurrence of GvHD or graft rejection

Presently, matching for $\mathrm{mH}$ antigens is not feasıble due to their number and polymorphism Quantitative, more than merely qualitative, differences in $\mathrm{mH}$ ant 1 gen-specific T-cell responses between recipients and their potental donors may be correlated with graft rc jection or GVHD Quancutauve differences may be estrmated by using limiting dilution assays to detcrmine CTL or T-helper-cell precursor frequencies as has been described in unrelated HLA-matched donor-recipicnt pars or allogeneic responder-stimulator pars by Kamınski et al $[40,41]$ and Deacock et al $[42]$, respectively Adapting these protocols to the specific situation of HLA-identical sibling BMT, e $g$, by using BMMNC, as stumulator cells, may produce valuable information

In conclusion, we have analyzed the $\mathrm{mH}$ antigen disparty between HLA-rdentical and -nonidentical famsly members of a paticnt with leukemia, and the possibility of finding a sibling bone marrow donor who was both HLA and $\mathrm{mH}$ antigen compatible In addition to compatibility for the mH antigens $\mathrm{HA}-1,-2,-4$, and -5 between bone marrow donor and recipient, disparity tor multuple other $\mathrm{mH}$ antigens was demonstrated both in the HvG and the GvH drectuons (TL lines were generated from PBLs from three other HLA identical sib lings by stumulation with donor BMMNC s, also recog nizing $\mathrm{mH}$ antigens expressed on cells from family members Donor-dnturecipient, but no restdual recipi ent-antidonor, reactivity was demonstrated at several intervals after BMT In view of these findings, hnding donor-recipient pars that are HLA and $\mathrm{mH}$ antigen identical is unlikely Quantitative, more than mertly qualitative, differences in the immune responses to $\mathrm{mH}$ antigens between recipients and their potential donors may more likely determine the incudence or severity of GvHD or gtaft rejection following HI Ambentical BMT

\section{ACKNOWLEDGMENTS}

The authors thank Dr $M$ Oudshoorn for the ILA DP oligonucleotide typing This study was supported in part by grants from the J A Cohen Instutute for Radiopathology and Radiation Protection J H $F$ Falkenburg is a Special lellow of the Royal Netherlands Academy of Arts and Sacnces

\section{REFERENCES}

1 Goulmy $\mathbf{E}$ Class 1 restricted human cytotoxic $\mathbf{T}$ lympho cytes directed against minor transplantation antigens and then possible role in organ transplantation Prog Allcrgy 3644,1985

2 Goulmy E Minor histocompatibility antigens in man and their role in transplantation Transplant Rev 2 29, 1988

3 Martin PJ, Hansen JA, Storb R, Thomds ED Human marrow transplantation an immunological perspectuve Adv Immunol 40 379, 1987

4 Neudorf S, Filipovich A, Ramsay N, Kersey J Preven tion and trearment of acutc graft versus host disedsc. Semin Hematol 2191,1984 
5 Mirtin PJ Hunsen JA Forok Storb B Dirnum D Prepurorka D OQuadey I Sanders J Sully un KM Witherspoon RP Dech HJ Appelbium $P$ Steward $P$ Water P Dones K Buckner C D Clife $R$ Scorb $R$ Thom is $C D \Gamma$ Ifects of in vitro deplction of $T$ cells in HI A rentical dilogencic murrow frafts Bone Murow Ttansplant 34451988

6 Kernan NA Gratt falure following trinsplane atson of T cell depleted murow [n Burakeff S] Deeg H i] Icrrar JLM Atkinson MK (cds) Graft scisus Host Dise ise Research and Clinical Man ifemene New York Mercel Dekker 1989 p 557

7 Mitsuyas RT Champlin RI Galc RP Ilo WG Lenarsks C Winston $D$ sclch $M$ Jlashoff $R$ Gworgi IV Wells ]

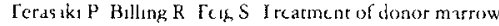
weth monoclonal ante $\mathrm{I}$ antibody ind complement for the prevention of ge ift ve rutus host dise ese Ann Intern Med 105201986

8 Haic G Cobbolds Waldm m H lor (ampith i uscers I cell depletion with Cempath 1 in allogencic bone marrow transplantdeon $\operatorname{Tr}$ insplant tton $45753 \quad 1988$

9) Bordizoon ( Keever ( A smill IN Homcabers $\mathrm{N}$ Dupont B Q Relly R Kerman NA Grift fulure after T

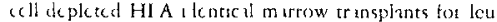
kemid il fir vitero an alyss of host effector mechanisms Blool $7+223$ 1980)

10) Kernan NA Flomenbers N Dupont B ORcilly RJ Grafe reyection in rccopicnts of $\mathrm{r}$ cell depleted HLA non adcrecic al marrow er insplantation for kukcmid Franspian tittion $43842 \quad 1987$

11 Ilaschinucr K Kernan NA ORcalls RJ Dupont B Yong, SY Bone marrow allogr ift rejection by T lymphes cytes recognuang a sank te tmano ked difference m IHLA But N Fonl I Mad 3231818 1900)

12 Donohuc J Keman NA Characterization of cells emerg ing at the time of sraft fallure ifter BMר from an unrc latcd marrow donor Blood $821023 \quad 1993$

13 Voog, PI libbe WH Marin WAT Goulmy I Vccnhof WTj Hamilton MS Brand A Zwan FL Willemee R Van Rood JJ Falkenburg JHI Rejecton of a bone mar ros graft by recipicent derived cytoroxic $\Gamma$ lymphocytes

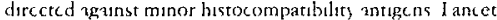
3351311990

14 Terasaku P Bernoco D Par MS Microdroplet testung for HLA $A$ B and $D$ antigens Am J Clin Pathol $69103 \quad 1978$

is Yans SY A standartiecd method for detection of HLA $A$ and IiLA $B$ alleles by one dimensional isoclectric fo cusing (II I) gel clectrophoresis In Dupont B (ed) His tocompatsbility lesting 1987 (Immunobiologs of $111 \mathrm{~A}$ ) vol 1 NEw York Springer Vcrla 1987 p 332

I6 Budwell JL Budwcil f A Laundy GJ Klouda PI Bradky $B A$ Allogenorvpes defincel by short DQA and DQB cDNA probes corrclate with ind define splits of IHLA DQ scrobotical specificutics Mol Immunol 245132987


the worhshop dedins d RTLP specilcaties in unrelite I in dividuals In Dupone B (cd) Hiscocomputibility Testrine 1987 (1mmunolony of HLA) woll Nex rork Springer Vertas, 1987 p 943

18 Van Els CACM D Amuro J Pool J Blokland F Bakkcr A Van Llsen PI Van Rood JJ Goulmy F Immunofenct is of human monor hustocomputibilty intigetis then polymorphism and immunodomen ane Immunogenetses $35161 \quad 1992$

19 Graft RJ Baley DW The non $H$ ' histocompattbility loce and their antigens Transplant Rev 15161973

20 Rammensec H G Klen J Polymorphism of minor histo compatiblity genes in wild mice Immunogenetics 176371983

21 Marıt WAF Vecohof WTJ Brand A Goulmy I ribbe Wilemec R Van Rood JJ I alkcnburg JHI Minor histo compatibility antugen specific cytocoxic T cell hines capa ble of lysing human lacmatoporetic progenutor cclls con be generated in vitro by stimul ition with HI A idenucal bone marrow cells J Exp Mcd $173101 \quad 1991$

22 Van Rood Jj V an Lceuncn A Plocm Js Simulancoua decection of two cell populations b; two colour fluores cence and tpplication to the tcoonnituon of B cell deter mulants Naturc 2627951976

23 Kimuia A Sasnzuks T Elcventh mincernationdal hustocom patibility workshop reference protocol for the HLA DNA typing technique in Tsujı K Asziwa M Sisazukı I (cds) HLA 1991 Proccedings of the 11 th Interna toonal Workshop and Conference lleld in Y ohohama Ja pan 6-13 November 1991 New Yotk Oxford Unver sity Press 1992 p 397

24 Goulmy $\mathrm{C}$ 1HLA A B rcstriction of c tocoxic $T$ cellis In Ferrone S Solheim BG (eds) HI A Typing Methodol oby and Chnacal Aspects vol 2 Ncw York CRC 1982 p 105

25 Gibbs PLM Zielınsky R Boyd C Duguczyk A Struc ture polymorphism ind novel repeatcd DNA clements reve ilc i by a complete sequence of the hum $\alpha$ fetopro tun go ne Brochemistry 2613321987

26 Wall yy $\mathrm{HJ}$ Raminensce $\mathrm{H} \mathrm{G} \mathrm{ldentification} \mathrm{of} \mathrm{clessic} \mathrm{al}$ min or histocomparsbifty antigen as cell derived peptide $\mathrm{N}$ ture 3432751990

27 I oveland BF Fischer Lindahl $K$ The definition and $e x$ pression of minor histocompatiblity antugens in $\mathrm{MC}$ Cluskey J (ed) Antigen Procsssing and Recognition Lon don CRC 1991 p 173

28 Wettstcin P) Minor histocompatibilit\} lou in Litwin SD (ed) Human Immunofencucs Ncw York Marcel Dekker 1989 p 339

29 Goulmy I Termutelen A Bridles BA Van Rood Jl Y antisen killing by $[$ cells of women is restrected by HI $A$ Nature $2665+4 \quad 1977$

30 Lier KS Llkins WL Pierson GR Lco MM The usc of cytotoxic $\mathbf{\Gamma}$ cell lines to detcet the segres teton of a buman

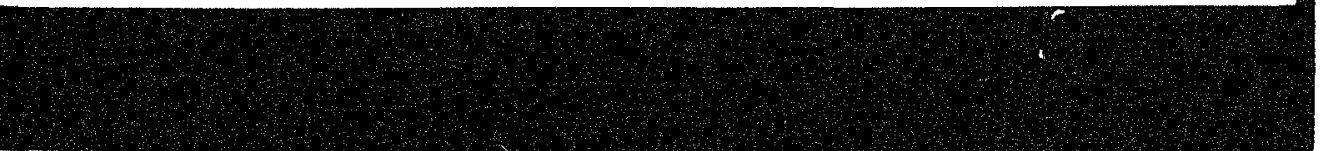


minor alloantigen withın families Hum Immunol 7117 , 1983

31 Irle C, Beatty PG, Mickelson E, Thomas ED, Hansen JA Alloreactive T cell responses between HLA-identical siblings detection of anti-minor histocompatibility $\mathrm{T}$ cell clones induced in vivo. Transplantation 40329,1985

32 Yamamoto J, Kariyone A, Akıyama N, Kano K, Takıguchı M Presentation of human minor histocompatibility antigens by HLA-B35 and HLA-B38 molecules Proc Natl Acad Sci USA 87 2583, 1990

33 Simpson E, Chandler P, Goulmy E, Disteche CM, Ferguson-Smith MA, Page DC Separation of the genetic loci for the $\mathrm{H}-\mathrm{Y}$ antigen and for testis determination on human Y chromosome Nature 326 876, 1987

34 McLaren A, Simpson E, Epplen JT, Studer R, Koopman $P$, Evans EP, Burgoyne PS Location of the genes controlling $\mathrm{H}-\mathrm{Y}$ antigen expression and testss determination on the mouse Y chromosome Proc Natl Acad Sci USA 856442,1988

35 Loveland B, Wang C-R, Yonekawa H, Hermel E, FisherLindahl K Maternally transmitted histocompatibility antugen of mice a hydrophobic peptide of a mitochondrially encoded protein Cell 60971,1990

36 Champlin RE, Ho WG, Mitsuyasu R, Burnison M, Greenberg P, Holly G, Winston DW, Ferg SA, Gale RP Graft farlure and leukemra relapse following $T$ lymphocyte-depleted bone marrow transplantation effects of intensification of immunosuppressive conditioning Transplant Proc 192616, 1987

37 Patterson J, Prentice HG, Brenner MK, Gilmore M,
Janossy G, Ivory K, Skeggs D, Morgan H, Lord J, Blacklock HA, Hoffbrand AV, Apperley JF, Goldman JM, Burnett A, Gribben J, Alcorn M, Pearson C, McVickers I, Hann M, Reid C, Wardle D, Gravett PJ, Bacigalupo A, Robertson AG. Graft rejection following HLA matched T-lymphocyte depleted bone marrow transplantation $\mathrm{Br}$ J Hematol 63 221, 1986

38 Kernan NA, Bordignon C, Heller G, Cunnıngham I, Castro-Malaspina $\mathrm{H}$, Shank B, Flomenburg N, Burns J, Yang SY, Black P, Collins N, O'Reilly RJ Graft fallure after Tcell-depleted human leukocyte antigen identical marrow transplants for leukemia I Analysis of risk factors and results of secondary transplants Blood 74 2227, 1989

39 Van Els CACM, Bakker A, Zwinderman AH, Zwaan FE, Van Rood JJ, Goulmy E Effector mechanisms in graftversus-host disease in response to minor histocompatibility antigens I Absence of correlation with cytotoxic effector cells Transplantation 5062,1990

40 Kaminskı E, Hows J, Man S, Brookes P, MacKinnon S, Hughes T, Avakian O, Goldman JM, Batchelor JR Prediction of graft versus host disease by frequency analysis of cytotoxic $T$ cells after unrelated donor bone marrow transplantation Transplantation 48 608, 1989

41 Kamınskı E, Hows J, Goldman J, Batchelor RJ Optımızing a limiting dilution culture system for quantitating frequencies of alloreactive cytotoxic $T$ lymphocyte precursors Cell Immunol 137 88, 1991

42 Deacock S, Schwarer A, Batchelor R, Goldman J, Lechler $R$ A rapid limiting dilution assay for measuring frequencies of alloreactive, interleukin-2-producing $T$ cells in humans J Immunol Methods 147 83, 1992 